\title{
The Effect of Story Telling Activity Using Pop-Up Book on the Social Caring Character
}

\author{
Luthfatun Nisa ${ }^{1, *}$ \\ ${ }^{1}$ Early Childhood Education Department, Institut Agama Islam Negeri Madura, Pamekasan, Indonesia \\ *Corresponding author. Email: luthfatunnisa@iainmadura.ac.id
}

\begin{abstract}
This study aimed to determine if the pre and post story telling activity of the social caring character could improve the character when the stories of the social caring character were read to kindergarten children. The story telling activity focused on the caring behaviour. The stories of social caring character were read to children using pop-up story book for experiment group $(\mathrm{N}=40)$. The control group $(\mathrm{N}=40)$ learned the caring character with no stories, but with conversing. The performance a quasi-experimental design, with nonequivalent control group design was used to data analyze. The result indicated that story telling activity of social caring character to treatment group significantly improved social caring character. A paired sample ttest score was significant $(0.000<0.05)$ on the social caring aspect. The conclusion was story telling activity of social caring character could influence the behavior of children's social caring character.
\end{abstract}

Keywords: Character education, social caring, style, story telling, preschool

\section{INTRODUCTION}

Since facing the 21st century the world of education has begun to transform in analyzing what children need to learn in facing the 21 st century. So, from the results of its analysis is a central institution the curriculum redesign describes four main dimensions of education today, namely: knowledge, skills, character, and metacognition. Character education is important as a reinforcement of the values of virtue that makes someone have wise considerations and decisions in social life. By this situation practitioners, academics, policymakers, make various updates and implement policies to include character education as an educational program.

One of the important characters embedded in children is "caring". Caring is an important value that needs to be introduced to early childhood. The values of caring can build a comfortable and more meaningful environment. The main value of caring is about learning to love and nurture each other (Swick, 2007). Broader caring is also interpreted by the desire to help others, and also the environment. Concern can have a big impact on a child's life, and that impact can be felt if the child knows and recognizes what manifestations of caring are. So this paper focuses on (1) explaining the benefits of character education embed in the educational environment and (2) explaining the implementation of character embed activities in helping children socialize with the environment.

Many Early Childhood Education Programs focus on the importance of children's social development, but children receive constant pressure to focus on cognitive development and literacy (Priest, 2007). Unfortunately, many children do not yet know about caring, so that in the lives of children often appears a number of behaviors that lead to violence both verbal and non-verbal. Violence in children's daily lives can take many forms, including physically, socially, verbally, and psychologically (Swick \& Freeman, 2004). Various behaviors that also often arise in children's daily lives are the lack of sensitivity of the child to help others, be ignorant, and do not want to share with friends. The emergence of children's ignorance in their social environment is one of the teacher's tasks to design programs or activities that can increase children's awareness.

Skills that are also important for children are prosocial behavior such as sharing, providing assistance, and mutual support among friends (Swick, 2001). These behaviors must go through an appropriate process, and all aspects of child development must be stimulated and developed not only in the cognitive aspects or children's literacy abilities. Character including important for children so that children have a tendency to be happy to help others, share food with friends and people around him. Indeed, it is not uncommon for skills and aspects beyond cognitive and language not to become the main priority in the learning process in Early Childhood Education Programs.

So that education for young children must return to its main path. One of the main goals of holding Early Childhood Education Programs is to help children learn to work together with others, caring for others, have verbal feelings, have friends, show kindness, and show their abilities and other qualities (Priest, 2007). Moreover, the purpose of education is not to acquire knowledge for itself, but to develop a disposition to seek and use knowledge in an effective and ethical manner (Shields, 2011). So that through education can prepare children who are not only experts in academics but also have a good personality, sensitive to others, and can know how to behave well. Therefore, it is necessary to develop in children some 
characters as a provision for them to face their lives both within the scope of family, friends, and the larger environment, such as the community.

Therefore an effort is necessary to introduce the meaning of caring for children one of them through storytelling. Storytelling is one strategy that can be done to introduce and embed the value of caring in children. In addition, storytelling is one of the most effective ways to develop children's self to have a view of caring. Through storytelling children can be introduced to the character values of responsibility, love, honesty, respect, care and so on (Turan \& Ulutas, 2016; Rahim \& Rahiem, 2013), it can be said that storytelling is one way to embed character in children. During the storytelling process, it is also necessary to discuss and share experiences so that children can exchange understanding and connect the knowledge that children have, experiences about helping others or shared with friends, and so forth. Thus the child can better understand the meaning of caring.

To better support storytelling activities, interesting media is needed so that children are easier to receive messages in the story. In this study using pop-up storybook media that contains content of socially caring characters in the setting of a child's school environment. This pop-up storybook is used as supporting media to find out the effect of storytelling activities to improve the social caring character of children.

So that the main objectives of this study are: (1) assessing children's social caring behaviors, and (2) identifying children's caring attitudes after storytelling activities in the learning process carried out at each opening of learning.

\section{LITERATURE REVIEW}

In a study conducted by (Freeman, 2014) about bullying in children, and the solution provided was to apply character education. They argue that by increasing literacy skills and implementing children's character education is a balanced solution. The use of literature in Early Childhood Education learning is very important to improve children's literacy skills and increase children's enthusiasm to apply them. In addition, storybooks are the most appropriate source of information for young children and are very fortunate to be able to understand children about good characters and prevent bullying. Assistance is carried out for 12 weeks where children openly and freely read bullying-themed storybooks, after which they are discussed and linked to their daily literature and activities which develop their thoughts and knowledge and use them and relate them to everyday problems, children's understanding about bullying increase and the incidence of bullying decreases. The difference between this research and previous research is on the character developed and the way the character is developed. In the research conducted by Freeman focused on preventing and reducing bullying behavior that often occurs in children through the development of character education programs and the application of literacy activities to improve children's character knowledge. Whereas this research focuses on improving children's social caring characters through storybooks that are developed with pop-up displays and containing social caring content so that children have knowledge about caring characters and can have behaviors that demonstrate social caring. Research conducted by Turan and Ulutas (2016) focused on the views and implementation of teachers about character education through picture story books, and teachers as role models in instilling character values in early childhood. While research conducted by Ahmadi, Fakhruddin, \& Khasanah (2017) entitled "the development of media pop-up books to improve 4th grade students' learning outcomes of civic education", examines the use of pop-up book media in improving children's leraning outcomes 4th grade elemantary school in citizenship lessons. The pop-up book content is about Indonesian cultures. In this research, the using of pop-up books as a medium to teach the love of the motherland through the introduction of the country's own culture.

In previous studies pop-up books have been widely used as a medium of learning in education. However, from various studies there are many that focused on the development of children's literacy, or as a medium for increasing the reading skill. Pop-up book has not been widely used as a storybook media that contains character values especially social caring characters. Therefore, in this study will discuss how the influence of story books with pop-up displays that contain stories with character values of social care for children.

\subsection{Character Education in Early Childhood Education}

Early childhood is an individual who is undergoing a process of development with a rapid and fundamental to the next life. According to psychologists, early age (0-8 years) is crucial for children to develop their potential. This age is often called the "golden age" which only comes once and cannot be repeated again. At this time what is conveyed to the child will be well received and absorbed, and this period is the right time to teach positive values including applying character education to children.

In the character education curriculum for the 21 st century as set out in the Center for Curriculum Redesign (Criteria \& Practices, 2013), it includes four main areas for children to learn, namely, knowledge, abilities, character, and metacognition, one of the four main areas is the character. In the 21 st century, character education is one of the main focuses and it is considered important because it is related to one's behavior with the surrounding community. Including early childhood who will not be separated from social relations. Children have a good ability to establish relationships with others, namely how children can understand themselves and others as people who have caring and politeness (Swick, 2001). This ability can be a provision in developing children's character because basically children already have good abilities in socializing. 
In addition, it refers to educational goals that have always wanted to foster students who are confident and loving and become successful students, who can contribute and serve the community as dignified citizens (Criteria \& Practices, 2013). One way to achieve educational goals is to help children get closer to the value of positive behavior and provide motivation through positive behavior by providing an understanding that children will feel the good things in themselves when they do good deeds too. Due to repeated positive or negative actions will become a habit, habits then become a character, and the character adheres to one's personal self (Flay \& Allred, 2010). Therefore, to achieve these goals requires individuals who are able not only in knowledge and abilities but also balanced with good character, and to produce the generation begins with character education.

\subsection{Cultivating Social Concern through Storytelling}

Caring is one of the main characters that are important to be owned by children, and caring has an affective aspect (Seidman, 2010) that can determine the quality of one's life. Caring makes a difference in the quality of life, various experiences or stories can provide knowledge and views about caring, and caring can have an impact on oneself and others in future lives. In a nurturing environment, the development of caring has a broad scope and specifically caring includes sharing and helping the relationship of children with friends at school. In addition, Freeman and Swick noted that, for more optimal feelings, caring is a form of mutually beneficial relationship where being a person who cares more and cares about giving and receiving experiences is an important part of the learning and development process in children (Freeman \& Swick, 2000).

Caring enters the realm of ethics because caring is considered a form of character that can be taught (Criteria \& Practices, 2013). One thing that is possible to be included in the education curriculum is related to caring characters. Caring characters include caring for oneself, caring for the people closest, caring for others and people in general, caring for nature and creatures outside of humans (plants and animals), man-made world, and also caring for ideas and thought (Noddings, 2014). Mutual respect, valuing everyone is the same and treating others lovingly and respecting differences are the main values of caring.

One method in developing caring characters is to use storytelling as a method to enhance thinking and a way to discuss moral issues including characters that are in them. Storytelling is not only a process of listening, but more than that. During the process of storytelling, noble values embed in children through appreciation of the meaning and intention of the story (Musfiroh, 2008, p. 19; Logan, Robinson, Rudisill, Wadsworth, \& Morera, 2014; Işıtan, 2016). Including the special character values of caring can be embedded in children through the process of storytelling, through storytelling can stimulate children in considering different points of view, exchanging views with others, and combining their own findings with existing knowledge (van den Heuvel-Panhuizen, Elia, \& Robitzsch, 2016). There are many activities that can be developed in storytelling, including sharing and discussing to express mutual understanding, and knowledge possessed.

\section{METHODS}

\subsection{Participant}

The object of this study consisted of 80 children who were divided into 2 groups, the control and experimental. Thus, in the control group, there were 40 children (15 girls, 25 boys) and in the experimental group, there were also 40 children (18 girls, 22 boys). The age of each child is $4-5$ years.

\subsection{Procedures}

There are several processes in the implementation of this research. Starting with the researcher conducted a variety of observations in kindergarten to find out whether there is an application of character education in early childhood, and how the caring behavior of children with friends around them or with their teachers, especially in children aged 4-5 years.

Observations made by the researcher to determine the extent to which children show caring behavior in friends or teachers, and in the process of observation the researcher assessed and then analyze as preliminary data to conduct further research. At the same time providing an overview of the situation and conditions in the field so that researcher could arrange research instruments in accordance with the conditions in the field.

Finally, the researcher conducted a pre-test, treatment, and post-test through a process of observing children's behavior conducted for 8 weeks, and the treatment process was carried out with storytelling activities using pop-up storybook media with the contents of the story about the values of caring and the background of the story. at school, inside and outside the room, and the characters in the story are the teacher and the children.

\subsection{Data Analysis}

At the field trial stage, the Quasi-Experimental Design was used. And using the Non-equivalent Control Group Design type. In this design it was almost the same as the pretestposttest group design, only in this design, the experimental group and the control group are not randomly selected. This method was used to compare between groups using pop-up storybook media with groups that did not use 
storybook media but only through conversational activities.

\section{RESULTS}

The average value in the aspect of social caring behavior shows almost the same value between the experimental group and the control group. The average value of aspects of social caring behavior in the experimental group was 28.67 and the control group was 29.1. Based on these average values, it can be seen that children have almost the same behavior.

Then the treatment process was carried out in the experimental group with storytelling activities using the media pop-up storybook, which previously opened with the apperception of children's experiences of social caring with the questions "have you ever seen your friends cry?", "Then, what did you do if you see your friend crying? "," what do you do when you see your friend falling? "," Do you like helping the teacher when you have trouble carrying something? ". Some of these questions were given to children to explore children's knowledge and Table 1 Paired samples test experiences about social caring and to accompany children's thoughts leading to the meaning of social caring through storytelling activities. Furthermore, after the treatment was completed, a post-test was carried out to retrieve the final data from the treatment results. After the treatment was carried out, then the post-test was conducted to find out the results of the treatment that has been applied.

The post-test activities were carried out the same as the pre-test, namely by observing the caring behavior of children who were assisted by their respective class teachers. Based on the post-test scores from the experimental group and the control group showed differences in the average value in aspects of social caring behavior. In the aspect of social caring behavioral aspects of the experimental group at 45.3 while in the control group at 31.97. Based on the average value in the experimental group and the control group both showed an increase in aspects of behavior, but in the experimental group showed a higher value increase than the control group. The result of hypothesis test is below.

\begin{tabular}{|c|c|c|c|c|}
\hline \multirow{2}{*}{} & \multicolumn{2}{|c|}{ Paired Differences } & \multirow{2}{*}{} & \\
\cline { 2 - 5 } & \multicolumn{2}{|c|}{$95 \%$ Confidence Interval of the Difference } & \multirow{2}{*}{ df } \\
\cline { 2 - 5 } & Lower & Upper & -11.852 & 39 \\
\hline \multirow{2}{*}{ Pre-Post } & 19.46221 & -13.78779 & 39 \\
\hline
\end{tabular}

Hypothesis testing in this study used paired sample t-test. Paired sample t-test results on aspects of social awareness behavior show that the calculated t value obtained was 11,852 . Based on the $t$ value of $11,852>1,684$ with a significance level of $5 \%$, and the results of the paired sample t-test showed a significance value of 0,000 which means that the value is smaller than 0.05 . If the sig value $<0.000$, it means that storytelling activities affect the social caring character of early childhood.

\section{DISSCUSSION}

Social caring is an important value and it is very important to embed in children. Before the storytelling activities with character-based pop-up storybooks were carried out, all the children did morning activities together in the hall. During the gathering in the hall, the children held a prayer activity together with one of the children appointed by the teacher.

Each class group entered into the center that has been scheduled. Each group enters the center and sits in a circle with the teacher and the teacher opened the learning by asking the day, date, month, and year. In addition, the teacher invited children to sing while clap singing songs according to the theme. Furthermore, the teacher began to introduce storybooks that were told to children in accordance with the provided manuals. When introducing storybooks, the teacher also makes apperceptions related to children's behavior or experiences about social caring. Apperception activities are carried out through conversation, then the teacher began to tell the contents of the book and involved the child in each story that was conveyed.

During the trial process, there are several factors that influence storytelling activities. In addition to characterbased pop-up story books which are the main factors that influence children's character improvement, the accuracy in the delivery of stories also has an impact on the process of receiving messages in the story. One of them is the position of the teacher in telling a story which influences the conduciveness of the class, the teacher who tells the story by sitting on a chair is easier to condition the child than the teacher must sit in line with the child or by standing. Because sitting in a chair makes it easier for children to see each object picture from a storybook when the book is opened. In addition, during the process of storytelling, it is more effective to explore and build children's knowledge through open questions. Because open questions give children more opportunities to answer in their own language (Trussell \& Easterbrooks, 2014; Knauf, 2018). Through open-ended questions, children are 
trained to process language and use the vocabulary they have.

\section{CONCLUSION}

Based on the pre-test value of children the value of social caring behaviors of children obtained a relatively low average value, but after being given treatment using a character-based pop-up storybook the aspect has increased as evidenced by the child's post-test score which is higher than the pre-test. So, it can be concluded that characterbased pop-up storybooks have proven to be effective and have an effect on increasing children's socially caring characters, and the kind character consists of understanding kindness, wanting kindness, and doing kindness or habits of mind, habits of heart, and habits of action ( Lickona, 1991, p. 72), and all of that can be stimulated through character-based pop-up storybooks.

\section{REFERENCES}

Ahmadi, F., Fakhruddin, T., \& Khasanah, K. (2017). The Development of Pop Up Book Media to Improve 4th Grade Students' Learning Outcomes of Civic Education. In 3rd International Conference on Theory \& Practice.

Criteria, D., \& Practices, G. (2013). Genetics education for the 21 st Century. (March), 2010-2011.

Flay, B. R., \& Allred, C. G. (2010). International research handbook on values education and student wellbeing. In International Research Handbook on Values Education and Student Wellbeing. https://doi.org/10.1007/978-90-481-8675-4

Freeman, G. G. (2014). The Implementation of Character Education and Children's Literature to Teach Bullying Characteristics and Prevention Strategies to Preschool Children: An Action Research Project. Early Childhood Education Journal, 42(5), 305-316. https://doi.org/10.1007/s10643-013-0614-5

Freeman, N. K., \& Swick, K. (2000). Serving and learning ata university laboratory school: Students from birth though adulthood benefit when service learning is integrated into the preservice curriculum. Journal of Early Childhood Teacher Education, 21(1), 93-105. https://doi.org/10.1080/0163638000210111

Işitan, S. (2016). Illustrated storybooks for preschool children published in Turkey between 1980-2013: A study based on preschool education reforms.

Educational Sciences: Theory \& Practice, 16(2).

Knauf, H. (2018). Learning Stories: An empirical analysis of their use in Germany. Early Childhood
Education Journal, 46(4), 427-434. doi:https://doi.org/10.1007/s10643-017-0863-9

Lickona, T. (1991). Education for character. New York: Bantam Books

Logan, S. W., Robinson, L. E., Rudisill, M. E., Wadsworth, D. D., \& Morera, M. (2014). The comparison of school-age children's performance on two motor assessments: The Test of Gross Motor Development and the Movement Assessment Battery for Children. Physical Education and Sport Pedagogy, 19(1), 48-59.

doi:https://doi.org/10.1080/17408989.2012.726979

Musfiroh, T. (2008). Memilih, menyusun, dan menyajikan cerita untuk anak usia dini. Yogyakarta: Tiara Wacana.

Noddings, N. (2014). in Education. doi:https://doi.org/10.1177/1477878510368617

Priest, C. (2007). Incorporating character education into the early childhood degree program: The need, and one department's response. Journal of Early Childhood Teacher Education, 28(2), 153-161. doi:https://doi.org/10.1080/10901020701366723

Rahim, H., \& Rahiem, M. D. H. (2013). The use of stories as moral education for young children. International Journal of Social Science and Humanity, 2(6), 454-458.

https://doi.org/10.7763/ijssh.2012.v2.145

Seidman, J. (2010). Caring and incapacity. Philosophical Studies, 147(2), 301-322. https://doi.org/10.1007/s11098-009-9428-0

Shields, D. L. (2011). Character: As the aim of education. Phi Delta Kappan, 92(8), 48-53. doi:https://doi.org/10.1177/003172171109200810

Swick, K. J. (2001). Nurturing decency through caring and serving during the early childhood years. Early Childhood Education Journal, 29(2), 131-137. doi:https://doi.org/10.1023/A:1012533230821

Swick, K. J., \& Freeman, N. K. (2004). Nurturing peaceful children to create a caring world the role of families and communities. Childhood Education, 81(1), 2-8.

doi:https://doi.org/10.1080/00094056.2004.10521284

Swick, K. J. (2007). Insights on caring for early childhood professionals and families. Early Childhood 
Education Journal, 35(2), 97-102.

doi:https://doi.org/10.1007/s10643-007-0180-9

Trussell, J. W., \& Easterbrooks, S. R. (2014). The effect of enhanced storybook interaction on signing deaf children's vocabulary. Journal of Deaf Studies and Deaf Education, 19(3), 319-332.

Turan, F., \& Ulutas, I. (2016). Using storybooks as a character education tools. Journal of Education and Practice, 7(15), 169-176.

van den Heuvel-Panhuizen, M., Elia, I., \& Robitzsch, A. (2016). Effects of reading picture books on kindergartners' mathematics performance. Educational psychology, 36(2), 323-346. 